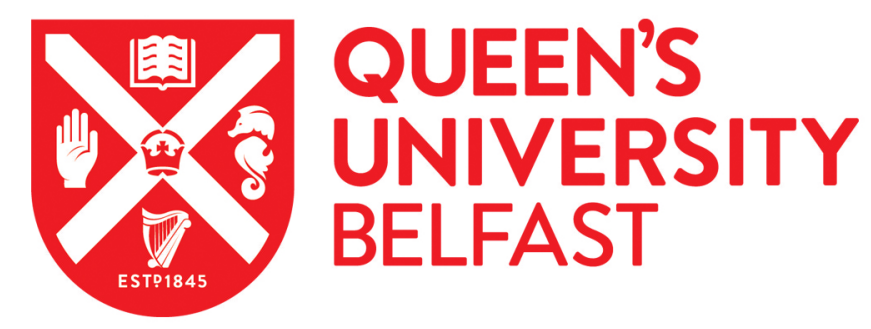

\title{
Moving beyond the rhetoric of provocation: the French and World War II in the novels of the Hussards (1949-1954)
}

Braganca, M. (2015). Moving beyond the rhetoric of provocation: the French and World War II in the novels of the Hussards (1949-1954). Journal of War \& Culture Studies , 8(3), 228-239.

https://doi.org/10.1179/1752628015Y.0000000015

Published in:

Journal of War \& Culture Studies

Document Version:

Peer reviewed version

Queen's University Belfast - Research Portal:

Link to publication record in Queen's University Belfast Research Portal

Publisher rights

Copyright 2015 The author

\section{General rights}

Copyright for the publications made accessible via the Queen's University Belfast Research Portal is retained by the author(s) and / or other copyright owners and it is a condition of accessing these publications that users recognise and abide by the legal requirements associated with these rights.

Take down policy

The Research Portal is Queen's institutional repository that provides access to Queen's research output. Every effort has been made to ensure that content in the Research Portal does not infringe any person's rights, or applicable UK laws. If you discover content in the Research Portal that you believe breaches copyright or violates any law, please contact openaccess@qub.ac.uk. 


\title{
Moving beyond the rhetoric of provocation: the French and the
}

\section{Second World War in the novels of the Hussards (1949-1954)}

\author{
Manu Braganca
}

\begin{abstract}
In the immediate aftermath of the Second World War, only those who had opposed the Germans or were perceived to have done so could freely express themselves. Soon, however, three young writers clearly leaning to the right of the political spectrum - Antoine Blondin, Roger Nimier and Jacques Laurent - dared to challenge their narratives in a series of provocative novels published between 1949 and 1954. Quickly referred to as the Hussards after the publication in 1952 of a famous essay by Bernard Frank, these writers momentarily occupied the literary space left vacant by their older peers. Without denying the provocative, political and subversive dimensions of the Hussards' war novels, this article will argue that their success was mainly due to the fact that they were largely in line - and not in contradiction - with the 'horizon of expectations' of their time (Jauss, 1982).
\end{abstract}

\section{Introduction}

Official and unofficial trials during the Liberation and in the immediate aftermath of the Second World War led to the execution of approximately ten thousand French collaborators (Rousso, 2001: 528), including the writers and journalists Georges Suarez in 1944 and Robert Brasillach in 1945. Other major writers such as Paul Morand and Louis-Ferdinand Céline fled France and went into exile at the end of the war to escape a similar fate. The climate of hatred 
and violence was such that many French intellectuals who had either collaborated with the Germans or who were suspected of having done so were reluctant to express their views on the war for many years after its end. In fact, in addition to the legal and to the wild purges, the Comité National des Écrivains (National Writers' Committee), clandestinely created during the war and increasingly Communist-dominated after the Liberation, put pressure on publishers to blacklist pro-Vichy or pro-Nazi writers after the war (Judt, 1992: 43-73; Assouline, 1996; Sapiro, 1999: 563-626).

Only those who had opposed the Germans or were perceived to have done so could freely express themselves in the immediate aftermath of WWII. As the sociologist Gisèle Sapiro put it (1999: 595), they had 'the monopoly of speech'. Many of their novels, often rewarded by the most prestigious literary prizes, became instant best-sellers. These included: Mon Village à l'heure allemande [literally 'my village on German time', translated into English as French Village] (Goncourt Prize 1945) by Jean-Louis Bory, Éducation européenne [European Education] (Critiques Prize 1945) by Romain Gary, Le Sang des autres [The Blood of Others] (1945) by Simone de Beauvoir, Les Forêts de la nuit [Forests of the Night] (Goncourt Prize 1947) by Jean-Louis Curtis, and the trilogy (or unfinished tetralogy) Les Chemins de la liberté [The Roads to Freedom] (1945-1949) by Jean-Paul Sartre. ${ }^{1}$ These novels, often conceived or even started during the war, focus on the Occupation: German characters are all males, soldiers and invaders. Moreover, since the action takes place in occupied territories, Germany is absent from the narratives. Often compared to robots and animals, German characters are de facto reduced to their military function, to their 'uniform', a word that, literally, means 'one form' or 'one shape'. Consciously or not, these writers repeated old stereotypes about Germans that can be found in Madame de Staël's De l'Allemagne [On Germany] (1813) for example or, closer to their

\footnotetext{
${ }^{1}$ The Goncourt Prize was, and still is, the most prestigious literary prize awarded in France.
} 
time, in some interwar accounts such as André Gide's 'Réflexions sur l'Allemagne' [Reflections on Germany], published initially in the prestigious review La Nouvelle Revue française in June 1919 and republished in 1924 in Incidences. In this essay, the French writer discusses 'the extraordinary difficulty for individuals of their [German] race to differentiate themselves from one another, from the crowd or, in other words, to be individuals' (Gide, 1924: 14). ${ }^{2}$ In fact, he goes even further and states that ' $[\mathrm{h}] \mathrm{e}$ - the German - does not oppose anything, does not have a proper shape or, rather, he waits for the frame to give him his shape: this is why he submits to methods, rules, adulation' (Gide, 1924: 15). A good German character - reminiscent of real Germans, such as Goethe, or of fictional ones, such as von Ebrennac, the central figure of Le Silence de la Mer [The Silence of the Sea] by Vercors $(1942)^{3}-$ appears in several of these novels. Significantly however, this character is an exception: he embodies the past, the good Germany of the nineteenth century and not contemporary Germany (Braganca, 2010). In these best-selling novels, collaboration, whilst not absent, is purely opportunistic and never ideologically driven: the border between 'us' (the French) and 'them' (the Germans) is hermetically sealed.

Soon, however, three young writers clearly leaning to the right of the political spectrum dared to challenge these narratives in three provocative novels published between 1949 and 1954, namely L'Europe buissonnière [Playing Hookey in Europe] (1949) by Antoine Blondin, Le Hussard bleu [The Blue Hussar] (1950) by Roger Nimier, a sequel of his first novel Les Épées [The Swords] (1948), and Le Petit Canard [The Little Duckling] (1954) by Jacques Laurent. Quickly referred to as Les Hussards after the publication in 1952 of a now famous essay by the writer and critic Bernard Frank, these three young right-wing writers momentarily occupied the literary space left vacant by their older peers after the war.

\footnotetext{
${ }^{2}$ All translations are my own.

${ }^{3}$ Clandestinely published in 1942, this short story would quickly become one the main symbols of the French intellectual resistance after the Liberation.
} 
Their age was clearly an asset: too young to have been too heavily involved during the war, ${ }^{4}$ they could challenge previous accounts of the war without fear. As Marc Dambre put it, '[s]ince they were not discredited, they could speak, and their youth excused and favored excess, defiance, and opposition' (2000b: 62). Nonetheless, however provocative the Hussards' WWII novels may have been, their excesses alone cannot single-handedly explain their success. Indeed, provocation in itself does not guarantee success: the commercial failure of Jean Genet's highly provocative WWII novel Pompes funèbres [Funeral Rites] (1948) will suffice to illustrate this point. ${ }^{5}$ On the contrary, as many scholars have pointed out, any success reveals some sort of underlying public expectation and demand. As the sociologist Robert Escarpit put it, a success 'expresses what the group was waiting for and reveals the group to itself' (1964: 110).

This article will argue that the 'succès de scandale' rhetoric is far too simplistic to explain the Hussards phenomenon. Without denying their provocative, political and subversive dimensions, and without denying their literary qualities either, this article will argue that, to a large extent, these novels were not in contradiction but in line with the 'horizon of expectations' of their time (Jauss, 1982). Firstly, by comparing them with the best-selling novels published in the immediate aftermath (1945-1949) in which Germans characters are the all too obvious arch-enemies (Braganca, 2012), it will show how the Hussards subtly shifted French perspectives on the war: in doing so, they did not simply oppose alternative Manichean views to those previously expressed but, instead, they wrote stories that were largely compatible with them. Secondly, an examination of the wider socio-

\footnotetext{
${ }^{4}$ Antoine Blondin was born in 1922 and Roger Nimier in 1925. Born in 1919, Jacques Laurent was the oldest of the three and, despite his relatively young age at the time, he occupied a secretarial post in the Information department of the Vichy government and was briefly imprisoned after the war (Saint Vincent, 1995: 95-137; Cresciucci, 2011: 57-62).

${ }^{5}$ This complex novel centres on the homoerotic fantasies of a French Milicien who is besotted by a German soldier during the Liberation of Paris. The novel 'infuriated most French readers' according to Genet's biographer Edmund White (1993: 281). It may however be more accurate to say that the public was largely unaware of this text since it was first printed in an edition limited to 1500 copies, before a revised and slightly less provocative version was reprinted by Gallimard in 1953 (Plunka, 1992: 89).
} 
cultural and political context of the period 1949-1954 will then underline how many tropes at the heart of the Hussards' fictional accounts as well as the novelists' non-committed 'literary posture' (Meizoz, 2007) conformed to the expectations of their time.

\section{Shifting perspectives on the war}

There is an obvious - and much discussed - provocative dimension in the Hussards' aforementioned war novels (Magny, 1951; Hewitt, 1996; Dambre, 2000b; Kylousek, 2001). The light-hearted and witty tone of the picaresque L'Europe buissonnière (1949) by Antoine Blondin could in itself be seen as provocative, as would the fact that Jacques Laurent refers to Alsatians as traitors in Le Petit Canard (1954: 210), one year only after the trial of the thirteen Alsatian 'malgré-nous' ('against our will') who had been forcibly incorporated in the SS division Das Reich, responsible for the massacre of Oradour-sur-Glane on the $10^{\text {th }}$ of June 1944. ${ }^{6}$ This provocative dimension may however be best exemplified by the life trajectory of François Sanders, the main character in Roger Nimier's Les Épées (1948) and its sequel Le Hussard bleu (1950): indeed, in these two novels, he successively joins the French Resistance, the pro-Vichy (if not pro-fascist) Milice française (French militia) and, finally, the French Army of Liberation, immediately after cold-bloodedly and for no apparent reason killing a person whom he presumes to be Jewish. Yet, however provocative or politically incorrect these novels may have been at the time, they still found a readership. Contrary to the prevailing understanding (Hamel, 2006: 33, to take a recent example), the first section of this article will argue that the Hussards' novels did not radically and openly contradict the

\footnotetext{
${ }^{6} 642$ French men, women and children were murdered by this SS division. This trial left France in shock as the Alsatians were heavily sentenced in first instance, in January 1953, despite the fact that they had been forcibly incorporated into the German army. They were finally acquitted a month later (see Jean-Laurent Vonau, 2003).
} 
best-selling novels published in the immediate aftermath of the war. Instead, it will show how they operated a triple shift in their narratives - temporal, spatial and generational - that offers different but to a large extent compatible perspectives on the war.

The first shift is a temporal one. Whereas the best-selling novels published in the aftermath focussed almost exclusively on the Occupation, the Hussards' war novels focussed much more on the end of the war, the Liberation of France, the invasion of Germany by the Allies and, for Laurent's novel, on the French purge. This shift in time was of course only possible because these novels were written after the end of the war.

This shift in time made possible a second shift in their narratives, a shift in space: by concentrating their attention on the end of the war, these writers depicted Germany (and, more generally, the Axis powers) not as invaders but as being invaded, occupied. And this spatial shift allowed the Hussards to explore very different topics. Most importantly, Germans (and their allies) become victims of the war. In Blondin's L'Europe buissonnière, the only inhabitants of Germany and Austria are civilians, old men, young women, children, crippled, amputated or disabled people. The reader is told that, since the Anschluss (the annexation of Austria by Germany in 1938),

there were no more dances by the river on Sundays. [...] the Musicians had silently disappeared in the environs of Stalingrad and the dancers were one-legged. [...] Sometimes, war would reach Gloggnitz [the Austrian village where this scene takes place], leaving behind an injured soldier who would smile at women in the Swann Hotel. More often though, war would take a young apprentice [...] and bring back a coffin and an empty helmet shortly afterwards. (Blondin, 1949: 337-8)

In Nimier's Le Hussard bleu, French soldiers describe Germany in ruins as they advance into its territory. The young soldier Saint-Anne, the youngest and most sensitive of them, 
notes for example that 'the trees were cut, the houses burnt' and 'the train station emaciated' in the unnamed German city of K. (1950: 87-88). In contrast, his captain, De Forjac, casually compares the French advance to a stroll or a race through 'dead bodies and ruins' (1950: 145). With few exceptions, the only Germans they encounter are old people, women, and children who, on many occasions, become the victims of the French invaders. Once, for example, a French soldier recalls that a German boy was shot by a French sergeant because he had raised his fist as the French were passing by (Nimier, 1950: 135). Scenes of rape are very often hinted at or recalled (80-81, 84-85, 99, 101, 109-10, and so on) rather than described (119-24); and for one French soldier, named Los Anderos, it is actually a duty for the Hussars to rape German women (71). In Laurent's Le Petit Canard, the main character is the young anti-hero Antoine, who joined the Légion des Volontaires Français contre le Bolchévisme (Legion of French Volunteers against Bolshevism, a collaborationist French militia) after an emotional shock. ${ }^{7}$ Referring to the atomic bombing of Hiroshima, he harshly condemns the selfrighteousness of the Americans and, by extension, of their Allies: 'The American bomb is self-righteous', he says, while awaiting his trial in jail. 'The misfortune of the Nazis is to have said: "We are monsters", to have written "Mein Kampf". Americans only write to condemn violence. But when they act, they use it. The fact that the Nazis were also duped brings them closer to me', he concludes (Laurent, 1954: 190). It is also interesting to note that, with one exception, Frédéric in Le Hussard bleu, there is no German Nazi character in these novels. But Frédéric is indeed an exception, mocked and singled out by the other Germans in this text $(333-9 ; 416-9)$. Furthermore, the fact that his name is 'frenchified' is puzzling, and certainly blurs or diminishes the importance or relevance

\footnotetext{
${ }^{7} \mathrm{He}$ had been duped by adults all his life, he concludes, when he realises that his girlfriend was having sex with both a Polish soldier and his history teacher.
} 
of his nationality. Finally, this shift in space allowed Nimier and Blondin to revisit Franco-German love stories: indeed, whereas all the Germans were males and soldiers in the novels published in the immediate aftermath, love stories develop between young French males and German women in Le Hussard bleu and L'Europe buissonnière. ${ }^{8}$

However, the third and most important shift that the Hussards operate in their novels is a generational one: their main characters are young people and their life trajectories owe a lot more to chance encounters and emotions than to ideology, reason and choice, which were core themes in the aforementioned best-selling novels published between 1945 and 1949. Instead, the Hussards' young characters end up swapping sides - several times in L'Europe buissonnière or Le Hussard bleu - but their motivations are never fully explained or developed and may therefore be interpreted as insouciance, disillusionment - two attitudes often associated with the Hussards -, or simply as naivety and lack of awareness. This said, adults are certainly not role models to trust or follow in these novels. In one of L'Europe buissonnière's rare serious passages, a young German boy admits that he simply does not understand what is going on when he and the Hitler Youth group to which he belongs are harshly criticised by a French prisoner of war, Superniel, who urges them to stop behaving like adults, and exhorts them 'to learn to play football' instead (Blondin, 1949: 347). In Le Hussard bleu, right from the incipit, the main character Sanders uncompromisingly and violently opposes generations and not nationalities:

I belong to a happy generation which was twenty years old when the civilized world came to an end. We were given the nicest present on earth: a period in which our enemies, who included almost

\footnotetext{
${ }^{8}$ In Nimier's novel, there are in fact two love stories or, rather, a love triangle story between two French soldiers (Sanders and Saint-Anne) and a German woman. In Blondin's novel, there are also two love stories, the first one that concerns the character of Superniel and the second - which is more a 'sexual coming-of-age' story concerning the character of Muguet.
} 
all our elders, count for nothing. As for your comfort and progress, we advise you to implement them to the best systems of collective burials. You will need them, I can assure you. Because, slowly, you will vanish from this earth, without having understood a thing about its clashes, roars, or the torches that we are waving. For twenty years, you idiots were discussing how to bring together the youth of the world in your meetings. You must be pleased now. We came together by ourselves, one morning, on the battlefield. But you cannot understand. (Nimier, 1950: 11)

Finally, Le Petit Canard by Jacques Laurent offers a lengthy comparison between Antoine and his father. Both share similar values and attitudes, despite the fact that the father is a WWI veteran who tried to join the Resistance during WWII whereas his son joined the profascist Légion des Volontaires Français after an emotional shock. Most notably, both of them refuse to lie before or during the trial, regardless of the possible consequences. As a result, Antoine is sentenced to death and executed. In an interview initially published in the review Carrefour and reprinted as a sort of foreword to his novel, Jacques Laurent uses legal terminology to argue that the role of the novelist is to look for 'attenuating circumstances' (Laurent, 1954: 8). By calling into question the fairness of the verdict delivered against Antoine, Laurent implicitly invites his readers to reflect on the sentences delivered against many other French who may simply have chosen the wrong cause for all sorts of reasons but not out of intellectual conviction or ideology during the war.

In these three novels, the generational shift is of the utmost importance because it deconstructs the Manichean 'French versus German' opposition portrayed widely in the novels published in the immediate aftermath. It goes without saying that, given the disillusionment that followed the war and the beginning of the Cold War, most contemporary French readers would of course have felt less certain of their political and ideological convictions after 1949, a crucial year in French and European history as we will see. 
The novels of the Hussards and the changing horizon of expectations of the period 19491954

Beyond these temporal, spatial, and generational shifts, these novels are also clearly in line with the wider political and socio-cultural context and horizon of expectations of their time. This continuity is manifested through the novelists' repetition of common tropes and themes, their adoption of attitudes of disillusionment, and their self-conscious positioning as nonpolitical writers.

First, many of the tropes, topoi, plots and themes developed in these novels are reminiscent of past or contemporary successful novels and films. To what extent the Hussards were aware or conscious of these is impossible to assert but their existence nonetheless demonstrates that there was already a public a priori receptive or sympathetic to some of their ideas or tropes in postwar France. Some of these topoi can undoubtedly be associated with the literary Right: for example, young people being misled by adults or teachers, as in Le Petit Canard, would certainly have reminded many readers of Les Déracinés (1897) by Maurice Barrès, a major writer and political figure of the French Right from the end of the nineteenth century until his death in 1923. However, most of these reminiscences would have been politically neutral and quite literary. For example, war as an opportunity to engage in sexual relations - a theme present in the three Hussards' novels - is the main topos of Le Diable au Corps [The Devil in the Flesh] (1923) by the young Raymond Radiguet, one of the major literary successes of the interwar period. ${ }^{9}$ Beyond literature, youth and coming-of-age stories - a very old artistic trope - were also central to several highly successful films of that time, including Les Enfants terribles (1950) by Jean-Pierre Melville

\footnotetext{
${ }^{9}$ This best-selling novel tells the story of a young married woman who has an affair with a fifteen-year-old boy while her husband is fighting at the front during WWI.
} 
(an adaptation of Jean Cocteau's 1929 novel), The Wild One/L'Équipée Sauvage (1953, 1954 in French) by László Benedek, with Marlon Brando, or Rebel without a Cause/La Fureur de vivre (1955, 1956 in French) by Nicholas Ray, with James Dean. Indeed, American culture became increasingly present in France after the Blum-Byrnes agreement in 1946 which opened the French market to American products, including its films, ${ }^{10}$ and it is hardly surprising that Roger Nimier would soon be called 'the French James Dean' (Dambre, 1989: 449; 480-5; 555) since, like Dean, he embodied the alienated and disillusioned rebel hero. Like him, he was also fond of fast cars and would die prematurely in a car crash in 1962. Alain Cresciucci's latest book about the Hussards is entitled Les Désenchantés [the Disillusioned] (2011). More accurately perhaps, the writer François Nourissier described them as 'désengagé[s] par désenchantement' ('uncommitted by disillusionment') (cited by Dufay, 2006: 64). ${ }^{11}$ What is certain however is that their disillusionment also reflected their time. The hopes raised during the war did not translate into a better political system in the aftermath. The Fourth Republic, established in 1946, had to rely on fragile coalitions to function and was therefore very unstable. It reminded many French of the pre-war regime, the Third Republic, so severely criticised for its lack of leadership and for playing politics instead of working towards a more democratic, progressive and ethical society. In addition, the tensions that rapidly emerged throughout the French empire as well as internationally with the start of the Cold War could only have reinforced their overall sense of disillusionment and confusion. ${ }^{12}$ The year 1949 is particularly important in French and European politics and culture. In itself, the division of Germany into two countries in 1949 no longer allowed a

\footnotetext{
${ }^{10}$ The American penetration of the French film industry is incredibly fast after the Liberation. In 1952, over $40 \%$ of films screened in France are American, according to Francis Bordat (1985). See also Wall (1987).

${ }^{11}$ This is indeed more accurate because these 'rebels without a cause' would soon find one in the Algerian war (1954-1962) (Cresciucci, 2003).

${ }^{12}$ Symbolically, the $8^{\text {th }}$ of May 1945, Victory in Europe day, also marks the beginning of the Sétif massacre in Algeria, which would quickly spread and cause several thousand deaths within days (Thomas, 2013). A few months later, in September 1945, the communist Vietminh led by Ho Chi Min would declare an independent Vietnam, which would trigger France's first major colonial war.
} 
simplistic vision of WWII. More generally and importantly, the 'grand narratives' centred on the Nation (with a capital ' $n$ ') were giving way to more personal ones in France: to quote the sociologist Pierre Mayol, 'up until 1949, the French were primarily concerned about the future of the nation; from 1949 they start to develop an interest in themselves' (Mayol, 1995: 30). Symbolically, it is also in 1949 that the rationing card system put in place during the war came to an end: in their everyday lives too, the war was becoming a worry of the past for the French. This shift is also reflected in the Hussards' war novels in which individuals try to get on with their lives rather than follow abstract ideals that had delivered so little after the war as the readers knew only too well with the benefit of hindsight.

Even though the Hussards often repeated that they were writing fiction for fiction's sake, and not ideologically- or politically-committed fiction, a clear political or ideological dimension can be found in their novels. This may well be because 'in the 1940s and 1950s in France, a program of literary provocation could only be a provocation of the political, whether it be involuntary, hidden, or deliberate' as Marc Dambre put it (2000b: 66). This statement may seem a bit too categorical but, whether Dambre is right or not, it is clear that the Hussards' non-political literary posture suited their time. It is with humour and panache that the Hussards openly opposed 'committed literature' which was both personified and promoted by Jean-Paul Sartre in the aftermath (Dambre, 2000a). Moreover, whilst this was not necessarily perceived at the time, 'committed literature' was already in decline and the most convinced écrivains engagés were expressing doubts about the possibility of changing the world by using their 'pen as a sword', in Sartre's phrase (1964: 212). Here again, the years 1949 and 1954 that frame this article chronologically - because they mark the respective publication dates of L'Europe buissonnière and Le Petit Canard - are both highly significant and symbolic. In 1949, Sartre published La Mort dans l'âme [literally 'death in the soul', translated into English as 'Iron in the Soul']. After L'Âge de Raison [The Age of 
Reason] (1945) and Le Sursis [The Reprieve] (1945), this volume was supposed to be the third of his WWII tetralogy Les Chemins de la liberté [The Roads to Freedom]. It would be his last and the tetralogy remained unfinished: as Sartre explained on several occasions, it did not make sense for him to keep writing about WWII after 1949, in a completely different historical and political context (Grell, 2005: 166; Beauvoir, 1981: 578). In fact, La Mort dans l'âme would be Sartre's last novel: from then on, Sartre explored other genres and media to express his political ideals. Marking the end of our chronological frame, Simone de Beauvoir was awarded the prestigious Goncourt Prize for Les Mandarins in 1954: this powerful novel reflects bitterly on the disillusionment and divisions of French intellectual résistants after WWII. This was not merely fiction: some former intellectual résistants, such as Jean Paulhan (1952), criticising the unfairness and harshness of the purges, wanted to leave the past behind in order to move forward; others, such as Jean Cassou (1953), were strongly opposed to doing so, regretting on the contrary that the judicial system had been too lenient (Paulhan and Flower, 2003). The wartime hopes that the French could remain united after the war had been quickly dispelled.

\section{Conclusion}

Reading the Hussards' novels in partial continuity with, rather than in opposition to, previous WWII novels and in the very specific context of the period 1949-1954 helps to understand their success and move beyond the simplistic 'succès de scandale' rhetoric. It also helps to understand why, not long afterwards, the 'old guard' of the literary French Right would feel more confident to express their views more directly on the Second World War. 
In Le Flagellant de Séville, published in 1951, Paul Morand, exiled in Switzerland, would only feel brave enough to give his personal perspectives on the Second World War through the fictional character of Don Luis, a Francophile and progressive Spaniard whose life is shattered by his well-intentioned 'collaboration' with Joseph-Napoléon Bonaparte at the beginning of the nineteenth century, when Spain was occupied by the French (Noort, 2001: 30-49). Morand would not be the only French writer or intellectual to refer to ' 1815 ' to reflect surreptitiously on ' 1945 ': as Anne Simonin demonstrated (1998), the years 1814 and 1815 would be used more or less explicitly by many writers to argue that traitors are nothing more than losers, at any time in history. André Thérive, another French writer suspected of collaboration with the enemy at the Liberation, ${ }^{13}$ quotes Talleyrand - a savvy diplomat who succeeded in getting through the Ancien Régime, the Revolution of 1789 and the Restoration in 1815 - in his timely Essai sur les trahisons [Essay on treason] (1951): ‘treason is a matter of dates' (Thérive, 1951: 68). In fact, Jacques Laurent himself would express similar views in an essay entitled Quand la France occupait l'Europe, 1792-1815 [When France occupied Europe, 1792-1815] (1948).

Finally, to rethink the Hussards in partial continuity with, rather than in opposition to, the dominant French literary field also helps to understand Louis-Ferdinand Céline's comeback. His novels Féérie pour une autre fois [Fable for another time] (1952) and Féérie pour une autre fois II (1954) had been largely ignored by the critics and the public alike. Yet, only three years later, D'un Château l'autre [From Castle to Castle] (1957), the first volume of his semi-autobiographical or, rather, autofictional 'German trilogy' would be a huge success. Céline was an incredibly talented writer and it could be argued that this novel was more accessible and better written than the two Féerie ones. There is however little doubt that his

\footnotetext{
${ }^{13}$ André Thérive was a French delegate to Weimar in 1942 and published in collaborationist reviews during the war.
} 
sudden return to the forefront of the French literary scene was also due to the energy and support of a special advisor to his publisher who was none other than Roger Nimier (Dufay, 2006). Here, we touch upon a neglected area of research, namely the important editorial role that Roger Nimier and Jacques Laurent played behind the scenes from the end of the 1940s until the end of the 1950s: Roger Nimier as advisor to Gallimard, as editor-in-chief of the weekly Opéra (1950-1952) and critic for many other journals and reviews including La Table ronde, Carrefour, Arts, Femina, and Bulletin de Paris (Dambre, 1989: 309-369; 2000a); Jacques Laurent as founder of the monthly La Parisienne (1953-1958), editor-in-chief of the weekly Arts (1954-1959) and also critic for many other journals and reviews but most notably for La Table ronde (Martel, 2011; 2012).

In 1956, Roger Nimier publicly and rather provocatively claimed that Céline deserved the Nobel Prize (Nimier, 1956). Unsurprisingly, it never happened. However, Céline's literary return in itself demonstrates that the Second World War had reached a safer distance in French memories. But, as is now well-known, this past would soon come back to haunt the French (Rousso, 1987; Morris, 1992; Conan \& Rousso, 1994; Flower, 2014).

\section{Acknowledgments}

The author would like to thank John Flower, Marco Grosoli, Peter Tame, Émile Chabal, Aubrey Porterfield and the anonymous reviewers for their suggestions.

\section{References}

Assouline, P. 1996. L'Épuration des Intellectuels. Bruxelles: Editions Complexe.

Barrès, M. 1897. Les Déracinés. Paris : Nelson. 
Beauvoir, S. de. 1945. Le Sang des autres. Paris : Gallimard.

Beauvoir, S. de. 1954. Les Mandarins. Paris : Gallimard.

Beauvoir, S. de. 1981 (1991). La Cérémonie des adieux. Paris : Gallimard.

Blondin, A. 1949 (1968). L'Europe buissonnière. Paris: Livre de Poche.

Bordat, F. 1985. Évaluation statistique de la pénétration du cinéma américain en France.

Revue française d'études américaines 24/25 : 225-248.

Bory, J.-L. 1945. Mon Village à l'heure allemande. Paris : Flammarion.

Bragança, M. 2010. Le bon Allemand dans les romans français de l'immédiat après-guerre: une erreur de casting ? Modern \& Contemporary France 18 (3): 329-342.

Braganca, M. 2012. La crise allemande du roman français. Oxford: 'Modern French Identities', Peter Lang.

Cassou, J. 1953. La mémoire courte. Paris: Éditions de Minuit.

Céline, L.-F. 1952. Féérie pour une autre fois. Paris: Gallimard.

Céline, L.-F. 1954. Féérie pour une autre fois, II: Normance. Paris: Gallimard.

Céline, L.-F. 1957. D’un Château l'autre. Paris: Gallimard.

Conan, E. \& and H. Rousso. 1994. Vichy, un passé qui ne passe pas. Paris: Fayard.

Cresciucci, A. 2003. Les Hussards et la guerre d'Algérie. In P. Baudorre, ed. La Plume dans la Plaie : Les écrivains journalistes et la guerre d'Algérie. Bordeaux : Presses Universitaires de Bordeaux, pp. 169-185.

Cresciucci, A. 2011. Les Désenchantés. Paris: Fayard.

Curtis, J.-L. 1947. Les Forêts de la nuit. Paris : Julliard.

Dambre, M. 1989. Roger Nimier, hussard du demi-siècle. Paris : Flammarion. 
Dambre, M. 2000a. 'Grognards et Hussards': contre-feu de Sartre ?. In M. Dambre, ed. Les Hussards : une génération littéraire. Paris : Presses de la Sorbonne Nouvelle, pp. 13-29.

Dambre, M. 2000b. The Politics of Provocation in the Hussards. South Central Review 17 (4): 61-71.

Dufay, F. 2006 (2010). Le soufre et le moisi: la droite littéraire après 1945: Chardonne, Morand et les Hussards. Paris: Tempus/Perrin.

Escarpit, R. 1964. Sociologie de la littérature. Paris : Presses Universitaires de France.

Flower, J. 2014. A continuing preoccupation with the Occupation. French Cultural Studies 25 (3-4): 299-308.

Frank, B. 1952. Grognards et Hussards. Les Temps modernes 86: 1005-1018.

Gary, R. 1945. Education européenne. Paris : Calmann-Lévy.

Genet, J. 1947. Pompes funèbres. Paris: A Bikini-Gallimard.

Gide, A. 1924 (1946). Réflexions sur l'Allemagne. In A. Gide. Incidences. Paris: Gallimard, pp. 11-21.

Grell, I. 2005. Les Chemins de la liberté de Sartre, genèse et écriture (1938-1952). Bern and New-York: Peter Lang.

Hamel, Y. 2006. La Bataille des mémoires. Montréal: Presses de l’Université de Montréal.

Hewitt, N. 1996. Literature and the Right in Postwar France. The story of the 'Hussards'. Oxford: Berg.

Jauss, H. R. 1982. Towards an Aesthetic of Reception. Minneapolis: University of Minnesota. Judt, T. 1992. Past Imperfect: French Intellectuals, 1944-1956. Berkeley and Los Angeles: University of California Press. 
Kylousek, P. 2001. La poétique subversive des hussards. Etudes Romanes de Brno 31 [online] [accessed 25 March 2015]. Available at:

http://www.phil.muni.cz/plonedata/wurj/erb/volumes-31-40/kylousek01.pdf

Laurent, J. 1948. Quand la France occupait l'Europe, 1792-1815. Paris : Le Portulan.

Laurent, J. 1954 (1985). Le Petit Canard. Paris : Les cahiers rouges, Grasset.

Magny, C.-E. 1951. Roger Nimier. Yale French Studies 8: 56-76.

Martel, J.-P. 2011. Jacques Laurent, de La Table Ronde à La Parisienne. Un franc-tireur dans la 'guerre des revues'. Interférences littéraires / Literaire interferenties 7: 237-253.

Martel, J.-P. 2012. Discordes à La Table ronde (1948-1954). COnTEXTES 10 [online] [accessed 25 March 2015]. Available at: http://contextes.revues.org/5035

Mayol, P. 1995. Consommateurs, encore un effort. In P. Gumplowicz \& J.-C. Klein, eds. Paris 1944-1954. Artistes, intellectuels, publics : la culture comme enjeu. Paris: Autrement, pp. 30-41.

Meizoz, J. 2007. Postures littéraires: Mises en scène modernes de l'auteur. Geneva :

Slatkine.

Morand, P. 1951. Le Flagellant de Séville. Paris : Fayard.

Morris, A. 1992. Collaboration and Resistance Reviewed: Writers and the "Mode retro" in Post-Gaullist France. Oxford and New York: Berg.

Nimier, R. 1948. Les Epées. Paris : Gallimard.

Nimier, R. 1950 (1959). Le Hussard bleu. Paris : Livre de poche-Gallimard.

Nimier, R. 1956 (2012). Donnez à Céline le prix Nobel! Les Nouvelles littéraires (18

October). Reproduced in M. Dambre, ed. Nimier. Paris: Éditions de L’Herne, pp. 165-167. 
Noort, K. P. v. 2001. Paul Morand: The Politics and Practice of Writing in Post-War

France. Amsterdam: Rodopi.

Nourissier, F. 1982. Hussards : on mobilise ! Le Point (22 March).

Paulhan, J. 1952. Lettre aux directeurs de la Résistance. Paris: Éditions de Minuit.

Paulhan, J. \& J. Flower. 2003. Autour de la Lettre aux directeurs de la Résistance de Jean

Paulhan. Exeter: University of Exeter Press.

Plunka, G. A. 1992. The Rites of Passage of Jean Genet. London: Associated University Press.

Radiguet, R. 1923. Le Diable au Corps. Paris: Grasset.

Rousso, H. 1987 (1990). Le Syndrome de Vichy. Paris: Points Seuil.

Rousso, H. 2001. Vichy, l'événement, la mémoire, l'histoire. Paris : Folio Histoire, Gallimard.

Saint Vincent, B. de. 1995. Jacques Laurent. Paris: Julliard.

Sapiro, G. 1999. La Guerre des écrivains, 1940-1953. Paris: Fayard.

Sartre, J.-P. 1945. L'Âge de raison. Paris : Gallimard.

Sartre, J.-P. 1945. Le Sursis. Paris : Gallimard.

Sartre, J.-P. 1949. La Mort dans l'âme. Paris : Gallimard.

Sartre, J.-P. 1964. Les Mots. Paris : Gallimard.

Simonin, A. 1998. 1815 en 1945 : les formes littéraires de la défaite. Vingtième Siècle. Revue d'histoire 59: 48-61.

Staël, Madame de. 1813 (1882). De l'Allemagne. Paris : Firmin-Didot.

Thérive, A. 1951. Essai sur les trahisons. Paris: Calmann-Levy. 
Thomas, M. 2013. Intelligence and the Transition to the Algerian Police State: Reassessing French Colonial Security after the Sétif Uprising, 1945. Intelligence and National Security 28 (3): 377-396.

Vercors. 1943. Le Silence de la Mer. Paris : Editions de Minuit.

Vonau, J.-L. 2003. Le procès de Bordeaux, les Malgré-Nous et le drame d'Oradour.

Strasbourg : Éditions du Rhin.

Wall, I. M. 1987. Les accords Blum-Byrnes. La modernisation de la France et la guerre froide. Vingtième Siècle. Revue d'histoire 13: 45-62.

White, E. 1993. Genet. London: Chatto and Windus.

\section{Filmography}

Les Enfants terribles. 1950. Directed by Jean-Pierre Melville.

Rebel without a Cause/La Fureur de vivre. 1955/1956 in English/French. Directed by Nicholas Ray.

The Wild One/L'Équipée Sauvage. 1953/1954 in English/French. Directed by László Benedek. 